\title{
A Case of Pseudogout without Radiographic Evidence of Chondrocalcinosis
}

\author{
by \\ M. Takeno. M. Sakaguchi, K. Ishikawa, O. Mori, \\ K. Izumi and M. Tamura \\ Department of Orthopaedic Surgery, \\ Kumamoto University Medical School, Kumamoto \\ (Director: Prof. T. Kitagawa)
}

\begin{abstract}
Articular chondrocalcinosis with both arthritis and abnormal calcium deposition in hyaline and fibrocartilage was first described as a clinical entity in 1958 by Zitnan and Sitaj (9). Subsquently McCarty et al. (3) identified calcium pyrophosphate dihydrate (CPPD) crystals from both synovial fluid and cartilaginous tissues using compensated polarized light microscopy, x-ray diffraction and infrared spectrophotometry in patients with articular chondrocalcinosis and termed CPPD deposition disease or pseudogout. Although a considerable variation of clinical features has been described $(1,4)$, pseudogout without radiographic evidence of chondrocalcinosis seems to be very rare and also difficult to determine a correct diagnosis. In this paper, a case of pseudogout without radiographic evidence in either involved or distant joints is presented.
\end{abstract}

\section{Case Report}

A 56 year-old-woman visited our hospital with intermittent right knee pain on September 5, 1981. On examination, the right knee joint was tender and painful at motion, but swelling, warmth, and redness were not observed. Roentgenograms of the right knee showed slight osteoarthritic changes but no evidence of calcification was detected (Fig. 1). A single intra-articular injection of corticosteroid gave remarkable symptomatic relief for about one month. On October 9, an acute attack of arthritis accompanying severe pain and marked effusion occurred in her right knee without any provoking causes. ESR was $38 \mathrm{~mm}$ per hour and leukocyte count was 13,400 per c. m. m. The values of serum calcium, phosphorus, alkaline phosphatase and uric acid were within normal limits. Aspiration of right knee revealed $30 \mathrm{ml}$ yellow turbid fluid resembling that of purulent arthritis. But, since the attack was as severe as that of gout and there was no bacterial growth in culture, an acute attack of gout or pseudogout was suspected. Examination of synovial fluid using compensated polarized light microscopy demonstrated the presence of weakly positive birefringent crystals with monoclinic and triclinic forms of CPPD crystals (Fig. 2). However, extensive radiographic surveys revealed no evidence of chondrocalinosis. Treatment with indomethacin resulted in marked improvement of symptoms within three weeks. However, she was aware of occasional severe pain and of giving way after being permitted to walk without aids. On December 7 , the right lateral meniscectomy was performed after confirming a lesion of the lateral meniscus by arthrography. The excised meniscus showed severe degenerated changes especially on the tibial side and the scattered calcium 


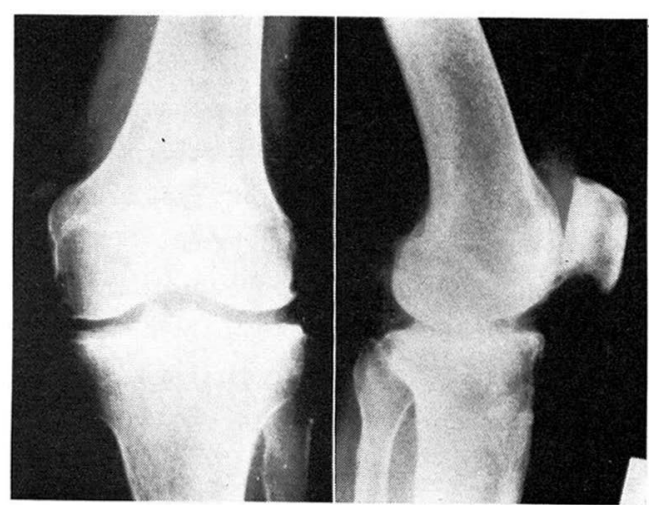

Fig. 1. Roentgenograms of the right knee joint without chondrocalcinosis.

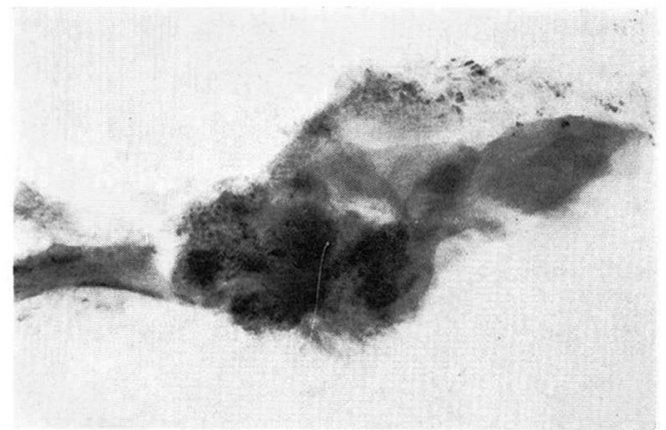

Fig. 3. Softex x-ray film of meniscus with calcification.

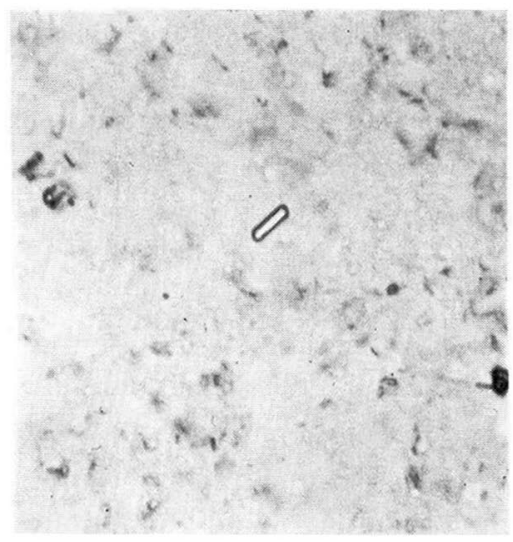

Fig. 2. Calcium pyrophosphate dihydrate crystals in synovial fluid (by compensated polarized light microscopy).

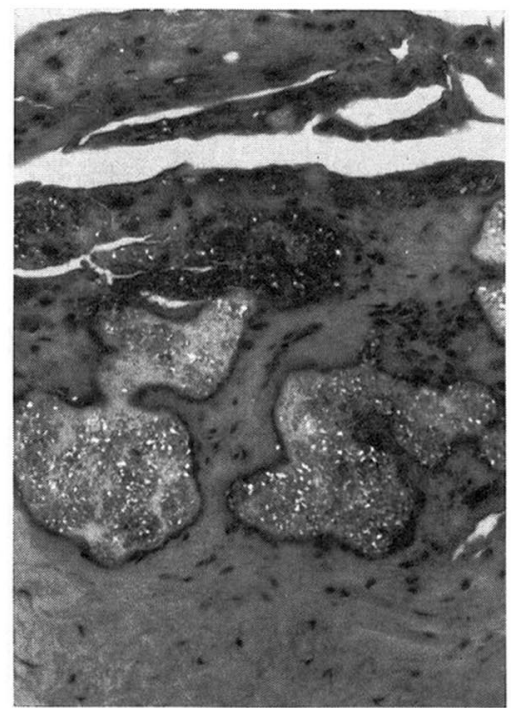

Fig. 4. Calcium pyrophosphate dihydrate crystals in meniscus (by compensated polarized light microscopy).

deposits were found on Softex x-ray films of the specimen (Fig. 3). Compensated polarized microscopy revealed large clusters of crystals with a weakly positive birefringence in the paraffin section (Fig. 4).

\section{Discussion}

Pseudogout is usually associated with radiographic evidence of chondrocalcinosis but similar to our report, several authors emphasize that pseudogout can occur without radiographic evidence of articular cartilage calcification $(2,6,8)$. According to the McCarty's 
revised diagnostic criteria (5), our case fell into "probable pseudogout" because CPPD crystals were not demonstrated by definitive means (e.g., x-ray diffraction powder pattern or chemical analysis). However, it seems to be justified to diagnose this case as pseudogout from the characteristic findings (7) of the removed meniscus. It is not seldom that acute arthritic attacks of pseudogout are as severe as those of gout and also accompany the moderate elevation of ESR and body temperature and leukocytosis which appear to be a systemic reaction. Such attacks are sometimes misdiagnosed as purulent arthritis (2). Diagnosis is much more difficult when acute attacks occur in patients without radiographic evidence of chondrocalcinosis which offers a great diagnostic clue to pseudogout. Therefore it is important to consider the possibility of pseudogout when we encounter unclassified acute arthritis particularly in elderly persons even when there is no evidence of chondrocalcinosis. And then, examination of synovial fluid should be carried out to identify CPPD crystals by using compensated polarized microscopy.

\section{Conclusion}

A patient of pseudogout showing no chondrocalcinosis on conventional roentgenograms is reported. Our experience indicates that examination by compensated polarized light microscopy of synovia fluid is essential for arriving to a the correct diagnosis.

\section{Acknowledgments}

The authors wish to thank Professor Toshio Kitagawa for his most helpful suggestions and criticism.

\section{References}

1) Bjells, A. and Sunden, G.: Pyrophosphate arthrophaty: a clinical study of fifty cases. J. Bone Joint Surg. (Br.) 56: 246-255, 1974.

2) Fam, A. G., Topp, J. R., Stein, H. B. and Little, A. H.: Clinical and roentgenographic aspects of pseudogout: a study of 50 cases and a review. CMA J. 124: 545-551, 1981.

3) McCarty, D. J., Kohn, N. N. and Faires, J. S.: The significance of calcium phosphate crystals in the synovial fluid of arthritic patients: the pseudogout syndrome, I. clinical aspects. Ann. Intern. Med. 56: 711-737, 1962.

4) McCarty, D. J.: Calcium phyroposphate dihydrate crystal deposition disease. Arthritis Rheum. 19: 275-285, 1976.

5) McCarty, D. J.: Calcium pyrophosphate crystal deposition disease: pseudogout: articular chondrocalcinosis. Arthritis and Allied Condition (McCarty, D. J. ed), 9th ed., Philadelephia. 1276-1299, 1979.

6) Pachas, W. N., Baltimore and Maryland: Pseudogout without chondrocalicinosis. a clinical radiologic and pathologic study of 18 cases. (Abst) Arthritis Rheum. 15: 121122,1972

7) Reginato, A. J., Schumacher, H R. and Martinez, V. A.: The articular cartilage in familial chondrocalcinosis. light and electron microscopic study. Arthritis Rheum. 17: 977-992, 1974. 
8) Utsinger, P. D., Zvaifler, N. J. and Resnick, D. : Calcium pyrophosphate dihydrate deposition disease without chondrocalcinosis. J. Rheum. 2: 3: 258-264, 1975.

9) Zitnan, D. and Sitaj, S.: Chondrocalcinosis articularis. section I. clinical and radiological study. Ann. Rheum. Dis. 22: 142-152, 1963.

質 問

1. 術前診断の方法は?

2. 遺伝性は?
宮崎医大 木村 干伋

解 答

1. 偏光顕微鏡でピロリン酸カルシウム結晶を認め たため, 半月板摘出以前から, 本疾患と考えた.

2. 遺伝性は本症例にはありません. 